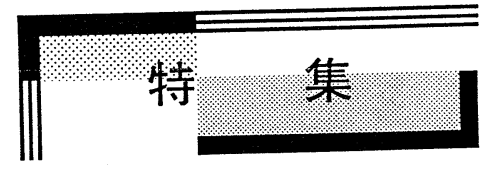

\title{
自然災害に打ける混相流 一土石流 -
}

Water / Sediment Two-Phase Flow Relating to Natural Disaster

- Debris Flow -

芦田 和 男 $^{* *}$
ASHIDA Kazuo

\author{
江 頭 進 治 ${ }^{* *}$ \\ EGASHIRA Shinji
}

\begin{abstract}
Multi-Phase flow is of ten related to natural disasters. Especially large flows cause drastic geomorphic changes and can lead to catastrophy in downstream areas. Debris flow is a typical two-phase flow in such phenomena. In this paper, the authors explain the behaviour of debris flow obtained by observations and experiments. A consititutive equation for debris flow is developed by considering the mechanism of energy dissipation in the flow of the mixture of water and sand particles. The consititutive equation is applied to discuss the distributions of velocity and particle concentration in uniform debris flow. The authors describe the characteristics of two-phase flow in catastrophic events by taking such examples as the Mt.St.Helens eruption, Mt. Asama's eruption and the Mt. Ontake land slide.
\end{abstract}

Keywords : Natural disaster, Debris flow, Debris avalanche, Mud flow,

Pyroclastic flow

\section{1. 緒言}

自然界には様々な混相流が存在するが、その中にはTable 1に示すように災害の原因となる ものが多い。とくに、規模の大きい混相流は、いわゆる天変地異に付随して現われることが多 く、大災害を引き起こす。

本論文では、自然災害に関係を持つ混相流の中で主として土石流と泥流を取り上げ、その実 態、発生の機構と発生の条件、流動の機構に関して主として著者らの行なってきた研究成果に ついて述べる。

さらに、規模の大きい混相流の実例として、St.Helensの噴火、浅間山の噴火および地震に よる御岳くずれの際に発生した土石流、泥流の実態について述べ、その流動特性について考察 する。

* 1991. 7. 21 受付

** 京都大学防災研究所

干611 宇治市五ケ庄 TEL (0774)32-3111 
Table 1 Multi-phase flow relating to natural disaster.

$$
\text { Gas-Solid }\left\{\begin{array}{l}
\text { Snow Avalanche } \\
\text { Debris Avalanche } \\
\text { Pyroclastic Flow }
\end{array}\right.
$$$$
\text { Liquid-Solid }\left\{\begin{array}{l}
\text { Debris Flow } \\
\text { Mud Flow }
\end{array}\right.
$$

\section{2. 土石流}

\section{1 土石流の実態}

わが国では、毎年のように土石流災害が発生している。土石流に関しては、ここ十数年の間 に現地観測 ${ }^{1)}$ が進みその実態が明らかになってきた。土石流 ${ }^{2), 3,4)}$ は、Photo. 1 および Fig. 1 に 示すように、巨磁が集まった段波状の先端部を持って抢り、これが高速で流下するため大きな 破壊力がある。先端部が通過した後は、比較的粒径も小さくなり、濃度も低くなって行く。単 一の波ではなくいくつもの波が間欠的に流下してくる場合が多い。横断面形状は、先端部では 凸型、後続部では凹型。土石流は谷の出口に出ると流動時の平面形状をそのまま凍結したかの ように堆積する。これを土石堆積という。土石流が何波も流出すると、谷の出口で首を振りな がらいろいるな方向に流れ、全体として円い土石流扇状地を形成する。

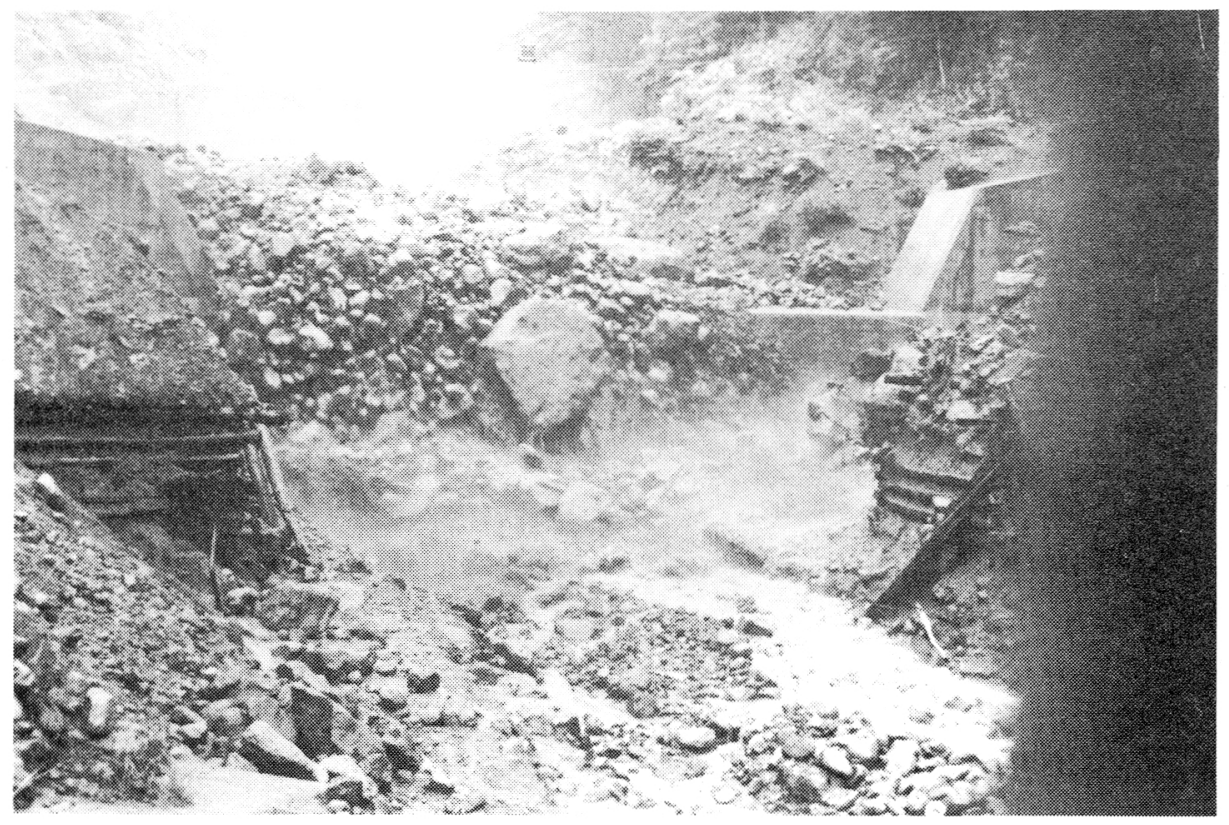

Photo 1 The front view of debris flow observed in Kami-Kami Hori Zawa,

Mt. Yake. Max. diameter is $3.1 \mathrm{~m}$.

(Dr. Suwa of Disaster Prevention Research Institute of Kyoto University) 


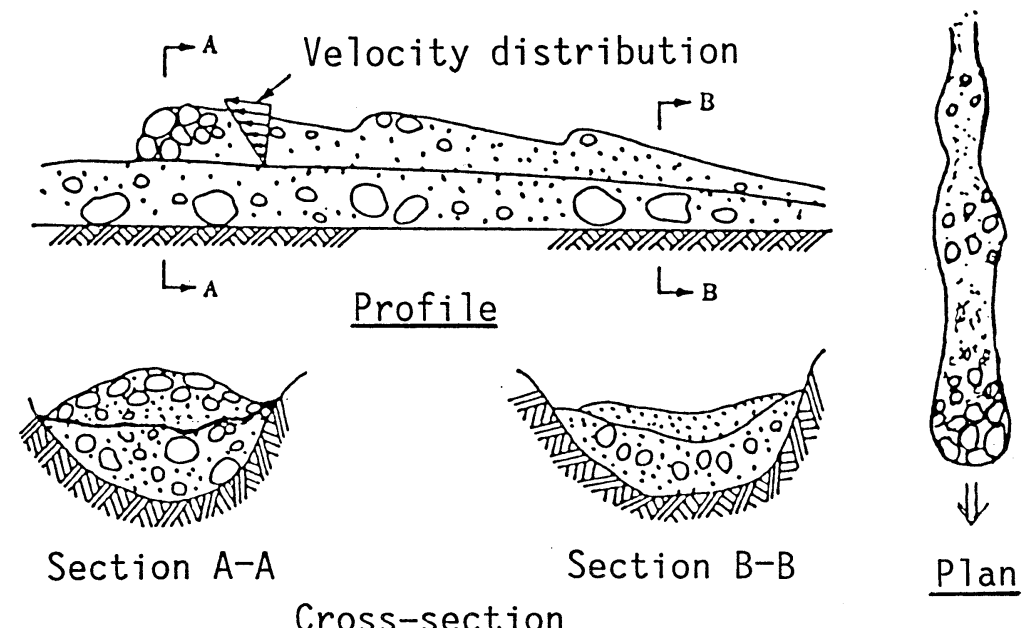

Fig. 1 The Shape of debris flow.

\section{2 土石流の発生条件}

土石流は、水と土砂・石磷の混合物の流れであるから、その発生には、移動可能な土砂・石 磷と水が同時に大量に供給されること、及び多量の石踏を含んでいることによって生じる抵抗 力に十分に打ち勝つだけの重力成分（急勾配）が必要である。土石流は主として次の三つの場 合浮発生する。

1 ）急勾配河床堆積物にある限界以上の表面流が発生する場合。

2 ) 山腹の崩壊土塊が土石流に移行する場合。山崩れが生ずるとしばしば大量の地下水が吹 き出すが、動きだした土塊の構造物が破壊され、水と混合して土石流となる場合が多い。

3 ) 天然ダムの決壊の場合。山崩れで渓流をせき止め、天然ダムが形成された場合、流水が 貯められ、やがて決壊して土石流となる。

斜面上の土層には、Fig. 2 に示すように、重力による作用力と砂磷の摩擦力（場合によって は粘着力も加わる）による抵抗力が働く。作用力が抵抗力を上をわる $a$ の部分が移動すること になる。勾配が急なほど $a$ の部分は大きくなる。 $a$ が粒径 $d$ より大きくなると、砂制の集合的 な流動が発生する。しかし、 $a$ が表面流の水深 $h$ に比べてかなり小さい場合には、Fig. 3 のよ らに、砂㸴は全断面に分散することができず、下層だけに土砂制の集中した、掃流状集合流動 が発生する。これも広義の土石流の中に含められている。勾配が急になるほど、aは厚くなり、

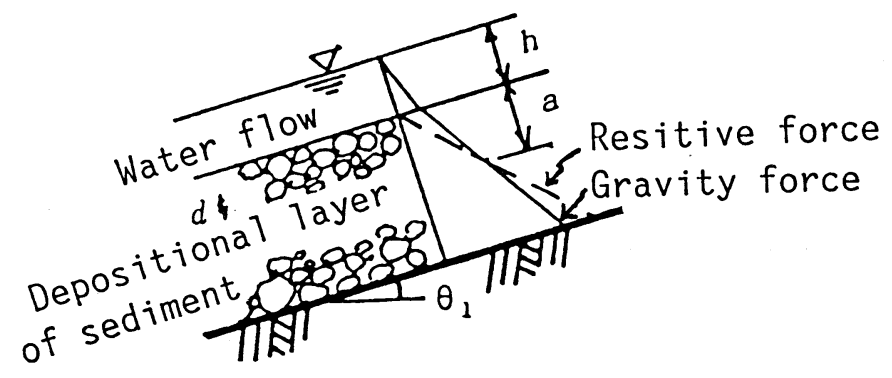

Fig. 2 Gravity force and resistive force acting on sediment deposited on a slope. 


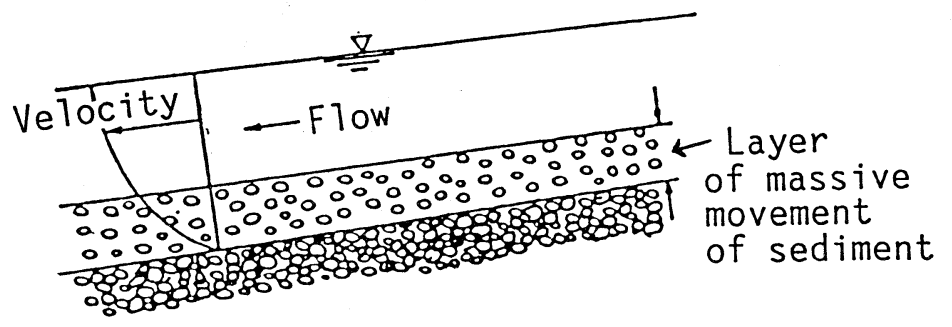

Fig. 3 Amateur debris flow.

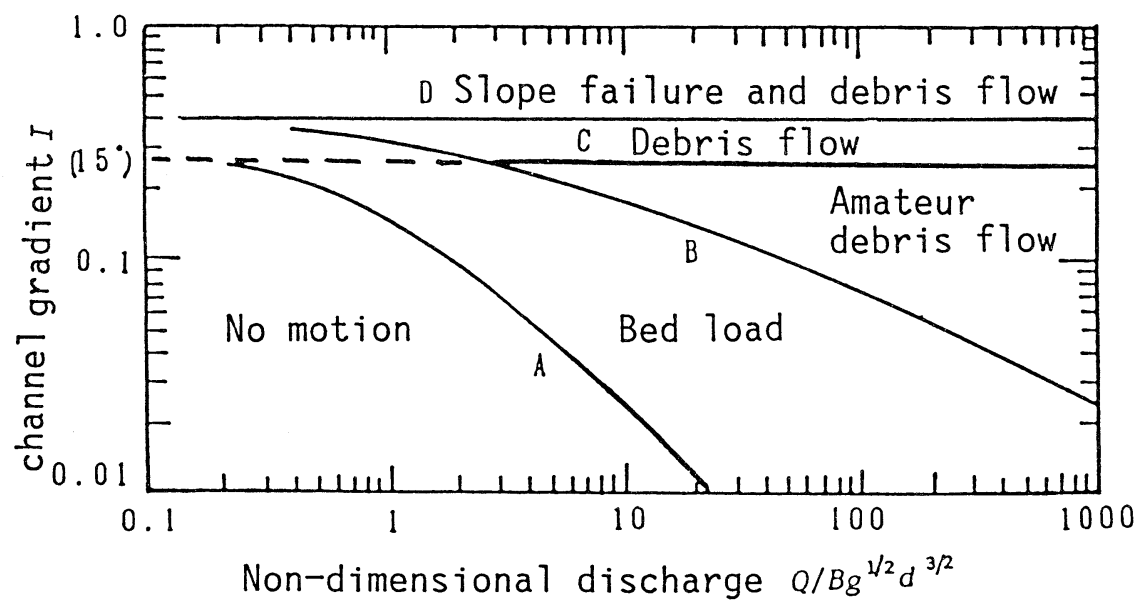

Fig. 4 Regime criteria of various sediment transport (non-cohesive material). (Takahashi, T.)

$0.7 \mathrm{~h}$ 程度になると砂碟の流動層が全水深に広がり、いわゆる土石流になる。非粘着性の砂磷 堆積層における各種流動形態の発生域を理論的に求めたものがFig. 4 で、その妥当性は実験に よって確かめられている。図中無次元表流水量中の $Q$ : 流量、 $B:$ 流路幅、 $g$ : 重力加速度、 $d:$ 平均粒径。

\section{3 土石流の流動則}

土石流は水と石磷との混合物の流れであって、その応力構造はニュートン流体とは本質的に 異なっている。

Bagnold ${ }^{5)}$ は、ニュートン流体と中立固体粒子との混合物を用いた実験によって応力とひず み速度の関係を調べ、応力には粘性領域と慣性領域とが存在することを明らかにした。彼は、 さらに独自の理論解析を行い、各領域における構成則を導いている。これらのらち慣性領域に おけるものを示せば

$$
\begin{aligned}
P & =f_{\mathrm{n}}(C, \sigma, d)(\mathrm{d} u / \mathrm{d} z)^{2} \\
\tau & =P \tan \alpha
\end{aligned}
$$

のようである。ここに、 $P$ は圧力、 $\tau$ はせん断応力、 $C$ は粒子体積濃度、 $\sigma$ は粒子密度、 $d$ は 
粒子径、 $\alpha$ は粒子の衝突角である。Bagnold の研究は、その後の土石流研究に大きな影響を与 えた。しかし、Bagnoldは上式の誘導に当って、粒子間には摩擦のない完全弾性衝突を想定し ている。そうすると、衝突によるせん断応力は発生しないことになるが、彼のモデルではせん 断応力が発生するとしており理論上の矛盾がある。その後、土石流の流動機構に関していろい ろな立場からの研究が進められて来た。まず、土石流の粒子間の衝突面あるいは接触面に作用 する力を詳細に調べる立場からの研究が進められている。これには、椿・橋本・末次”、

Ackerman・Shen など多数の研究がある。もら一つの研究の流れは、連続体力学の原理に則 して構成式を決定しょうとするものであって、これが粒子流研究の中心をなしている。これに は数多くの研究があるが、なかでも、応カテンソルを保存カテンソルと散逸カテンソルに分け て、これらをエネルギー方程式に基づいて議論しようとする立場からの研究は、Control vol umeの内部におけるエネルギー收支によって応力が決定されると考兄ている点において連続 体の原理に忠実であって、大きな可能性を秘めている。その代表的なものとして、金谷”宮 本 ${ }^{10)}$ の研究が挙げられる。金谷" は、固気混相流を対象として、これを非縮性の領域と压縮性 の領域に分けて取り扱った。ここで、保存カテンソル（压力）は、非匠縮性領域においては粒 子接点反力からなり、压縮性領域に扎いては粒子変動速度の運動エネルギーと関係づけて定式 化した。さらに、粒子の接触や衝突時に打ける粒子間摩擦を考兄、仮想仕事の原理を適用して エネルギー散逸関数を導き、これに基づいて散逸応カテンソルを導いている。

宮本 ${ }^{100}$ は、固液混相流を対象として、粒子衝突の前後において保存される運動エネルギーが 保存力（压力）を構成するすのとし、一方、衝突時に失なわれる運動エネルギーが散逸力にな るものとしてエネルギー散逸関数を導き、散逸応力（せん断応力）を定式化した。だだし、こ の研究において粒子と流体との相互作用によるエネルギー散逸は反発係数の中に含められてい る。

著者ら ${ }^{11)}$ も上同様に連続流体の立場から、土石流の流動機構に関する研究を行なっている。 その基本的な考方方は次のと拈りである。土石流のエネルギー散逸は、粒子間の摩擦、粒子の 非弾性衝突および粒子間の間隌水の乱れによるものであるとして、それぞれの散冕を評価し、 それに基づいて応力の構造を明らかにする。ついで、流速分布則拉よび濃度分布則を導く。

単位時間；単位体積当たりのエネルギー散逸量 $\Phi$ は、

$$
\Phi=\tau_{i j} \partial u_{i} / \partial x_{j}
$$

ここに、 $\tau_{i j}:$ 散逸応カテンソル

ここで、最も簡単な場合として、粒径一様の固体粒子と水との混合物を対象として、Fig. 5 K 示すような等流を考㝋る。上述のと拈り、散逸関係 る。すなわち、

$$
\Phi=\Phi_{\mathrm{s}}+\Phi_{\mathrm{g}}+\Phi_{\mathrm{f}}
$$

ここに、 $\Phi_{\mathrm{s}}$ は粒子間摩擦による散逸であり、粒子が下方の粒子を乗り越えるときの損失、 $\Phi_{\mathrm{g}}$ は粒子の非弾性衝突によって失なわれる運動エネルギー、沽は間隙を占める水の乱れによる 散逸である。

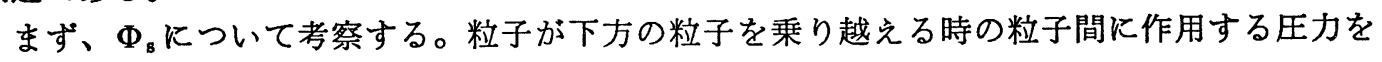
$P_{\mathrm{s}}$ とすれば、

$$
\Phi_{\mathbf{b}}=\mathrm{P}_{\mathbf{b}} \cdot \tan \varphi_{\mathbf{s}} \cdot \frac{\partial u}{\partial z}
$$



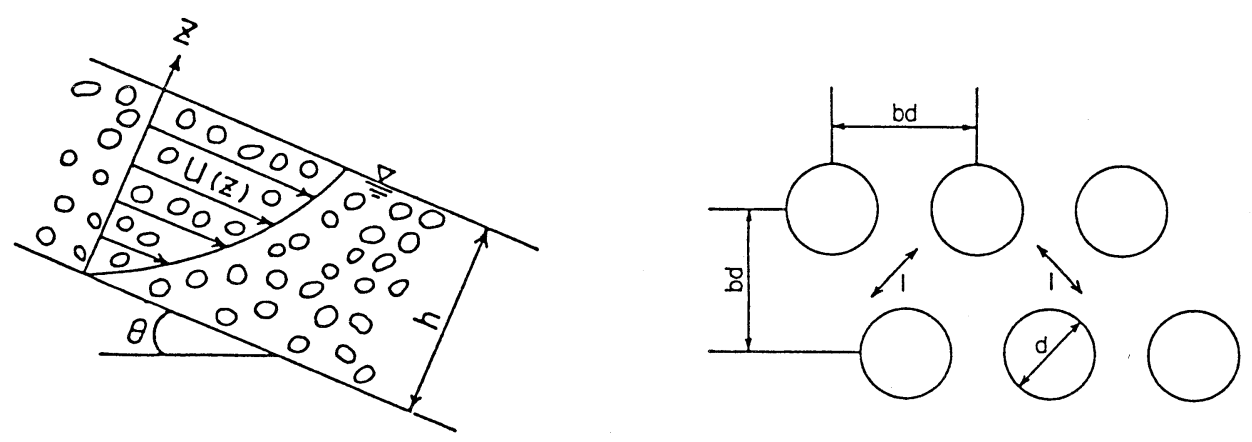

Fig. 5 Coordinate system of uniform debris flow and model of the granular-water mixture.

ここに、 $\varphi_{\mathrm{B}}$ は粒子間の摩擦角である。

また、 $\Phi_{\mathrm{g}}$ については宮本の研究を適用すれば、

$$
\Phi_{\mathrm{g}}=\frac{\pi}{12}\left(\sin ^{2} \alpha_{i}\right)\left(1-e^{2}\right) \sigma \cdot \frac{d^{2}}{b}\left(\frac{\partial u}{\partial z}\right)^{3}
$$

ここに、 $\alpha_{i}$ は粒子の衝突角、 $e$ は反発係数、 $\sigma$ は粒子の密度。 $b$ を粒子の体積濃度 $c$ に変換し て上式を書き表わすと、

$$
\Phi_{\mathrm{g}}=\mathrm{K}_{\mathrm{g}}\left(1-e^{2}\right) \sigma d^{2} C^{1 / 3}\left(\frac{\partial u}{\partial z}\right)^{3}
$$

ここに、

$$
K_{\mathrm{g}}=\frac{\pi}{12}\left(\frac{\pi}{6}\right)^{-1 / 3} \sin ^{2} \alpha_{i}
$$

宮本によれば、 $K_{\mathrm{g}}=0.0828$ 。

Ф については、乱れの混合距離を間陧のスケール $l$ とすね゙、

$$
\Phi_{\mathrm{f}}=\rho(1-C) l^{2}\left(\frac{\partial u}{\partial z}\right)^{3}
$$

$l$ を粒径 $d$ と濃度 $C$ を用いて表わせば、

$$
l=\sqrt{K_{\mathrm{f}}}\left(\frac{1-C}{C}\right)^{1 / 3} \cdot d
$$

ここに、 $\sqrt{K_{\mathrm{f}}}$ は粒子および間陌の形状係数比から定まる係数である。 したがって、

$$
\Phi_{f}=\rho K_{f} \frac{(1-C)^{5 / 3} d^{2}}{C^{2 / 3}}\left(\frac{\partial u}{\partial z}\right)^{3}
$$

式（5)、（7）および（11）を用いて式（4）を書き表わせば、

$$
\Phi=P_{\mathrm{g}} \tan \varphi_{\mathrm{s}} \frac{\partial u}{\partial z}+K_{\mathrm{g}}\left(1-e^{2}\right) \sigma d^{2} C^{1 / 3}\left(\frac{\partial u}{\partial z}\right)^{3}
$$




$$
+K_{\mathrm{f}} \rho d^{2} \frac{(1-C)^{5 / 3}}{C^{2 / 3}}\left(\frac{\partial u}{\partial z}\right)^{3}
$$

上式を式（3）を用いて、せん断応力 $\tau \cdot$ の式で表わすと、

$$
\begin{aligned}
\tau= & P_{\mathrm{s}} \tan \varphi_{\mathrm{s}}+K_{\mathrm{g}} \sigma\left(1-e^{2}\right) d^{2} C^{1 / 3}\left(\frac{\partial u}{\partial z}\right)^{2} \\
& +K_{\mathrm{f}} \rho d^{2} \frac{(1-\mathrm{C})^{5 / 3}}{C^{2 / 3}}\left(\frac{\partial u}{\partial z}\right)^{2} \ldots \ldots \ldots \ldots \ldots \ldots \ldots
\end{aligned}
$$

上式の右辺第 1 項は Yield Stress、第 2 項は粒子衝突による Stress、第 3 項は間隙水の乱れに よる Stressである。

圧力 $P$ は間隙水圧 $P_{\mathrm{w}}$ 、粒子間の静的圧力 $P_{\mathrm{s}}$ および粒子の衝突に伴なう動的圧力 $P_{\mathrm{d}}$ から成っ ている。

$$
P=P_{\mathrm{w}}+P_{\mathrm{s}}+P_{\mathrm{d}}
$$

$P_{\mathrm{w}}$ は静水压分布に従うものとして、次式で表わされる。

$$
\frac{\partial P_{\mathrm{w}}}{\partial z}=-\rho g \cos \theta
$$

$P_{\mathrm{d}} / P_{\mathrm{s}}=\alpha$ とおけば、

$$
\frac{\partial P_{\mathrm{s}}}{\partial z}=-\frac{\rho(\sigma / \rho-1) C g \cos \theta}{1+\alpha}
$$

ここに、

$$
\alpha=\tan \varphi_{\mathrm{s}} / \tan \varphi_{\mathbf{k}}-1 \approx 0.25
$$

$\varphi_{\mathrm{B}} 、 \varphi_{\mathrm{k}}$ はそれぞれ粒子の静摩摖角および動摩擦角。

動的圧力 $P_{\mathrm{d}}$ は、粒子衝突の際、保存される運動エネルギーから算定することが出来る。宮 本 は次式を導いている。

$$
P_{\mathrm{d}}=K_{\mathrm{g}} \sigma \mathrm{e}^{2} C^{1 / 3} d^{2}\left(\frac{\partial u}{\partial z}\right)^{2}
$$

式（14）、(15)、（16）および（18）から

$$
\begin{aligned}
& \frac{\partial P}{\partial z}=-p g \cos \theta-\frac{\rho}{1+\alpha}\left(\frac{\sigma}{\rho}-1\right) C g \cos \theta \\
& +K_{\mathrm{g}} \sigma \mathrm{e}^{2} d^{2} \frac{\partial}{\partial z}\left\{C^{1 / 3}\left(\frac{\partial u}{\partial z}\right)^{2}\right\}
\end{aligned}
$$

てに関する式（13）および $P$ に関する式（19）が土石流の流動に対する構成式である。この 構成式を用いて土石流の流速分布および濃度分布を算定することができる。いま、最も簡単な 場合として二次元等流の土石流の場合を示そう。二次元等流状態における土石流の応力の釣合 
い式は、

$$
\begin{aligned}
& \rho_{\mathrm{m}} g \sin \theta+\frac{\partial \tau}{\partial z}=0 \\
& \rho_{\mathrm{m}} g \cos \theta+\frac{\partial P}{\partial z}=0
\end{aligned}
$$

ここに、 $\rho_{\mathrm{m}}=\rho\{(\sigma / \rho-1) C+1\}$

式（20）および（21）式に式（13）および（19）を代入するとこによって、土石流の流速分布 および濃度分布を算定することができる。流速分布および濃度分布は相互に関係するので、正 確な分布形を求めるためには、絽り返えし試行計算が必要である。しかし、流速分布の第一近 似は一定濃度を仮定して次式で与えられる。

$$
\frac{u(z)}{\sqrt{g h}}=\frac{2}{3} K\left\{1-\left(\frac{h-z}{h}\right)^{3 / 2}\right\}
$$

ここに、

$$
\begin{aligned}
& K=\frac{h}{d}\left\{\frac{G-Y}{f_{\mathrm{f}}+f_{\mathrm{g}}}\right\}^{1 / 2} \\
& G=\{(\sigma / \rho-1) C+1\} \sin \theta \\
& Y=\frac{1}{1+\alpha}\left(\frac{\sigma}{\rho}-1\right) C \cos \theta \tan \varphi_{\mathrm{s}} \\
& f_{\mathrm{f}}=K_{\mathrm{f}} \frac{(1-\mathrm{C})^{5 / 3}}{C^{2 / 3}} \\
& f_{\mathrm{g}}=K_{\mathrm{g}} \frac{\sigma}{\rho}\left(1-\mathrm{e}^{2}\right) \mathrm{C}^{1 / 3}
\end{aligned}
$$

濃度分布の第一近似は、

$$
\frac{z}{h}=1-\exp \left[-K_{\mathrm{f}}\left(\frac{h}{d}\right)^{-2} K^{2} \int_{C_{0}}^{C} \frac{f_{\mathrm{n} 1}}{f_{\mathrm{n} 2}} \mathrm{~d} z / h\right]
$$

で与えられる。

ここに、

$$
\begin{aligned}
& f_{\mathrm{n} 1}=\left(\frac{1-C}{C}\right)^{5 / 3}+\frac{5}{3}\left(\frac{1-C}{C}\right)^{2 / 3} \\
& f_{\mathrm{n} 2}=G-Y-\alpha_{1}(1-C)^{5 / 3}-\alpha_{2} C
\end{aligned}
$$




$$
\begin{aligned}
& \alpha_{1}=\frac{K_{\mathrm{f}}}{K_{\mathrm{g}}} \frac{\alpha}{1+\alpha} \frac{\sigma / \rho-1}{\sigma / \rho} \frac{1}{\mathrm{e}^{2}} \cos \theta \\
& \alpha_{2}=\frac{\alpha}{1+\alpha}\left(\frac{\sigma}{\rho}-1\right) \frac{1-e^{2}}{e^{2}} \cos \theta
\end{aligned}
$$

Fig. 6 は、土石流の流速分布および濃度分布の実験值と計算值を比較したものである。計算 に用いた定数は $\alpha=0.25 、 K_{\mathrm{f}}=0.25 、 K_{\mathrm{g}}=0.0828 、 e=0.85 、 \varphi_{\mathrm{s}}=38.5^{\circ}$ である。また、Fig 中の $\theta$ は河床勾配、 $d$ は実験用砂の粒径、 $C$ は容積濃度、 $q_{\mathrm{m}}$ は単位幅当りの土砂之水の混合 物の流量。
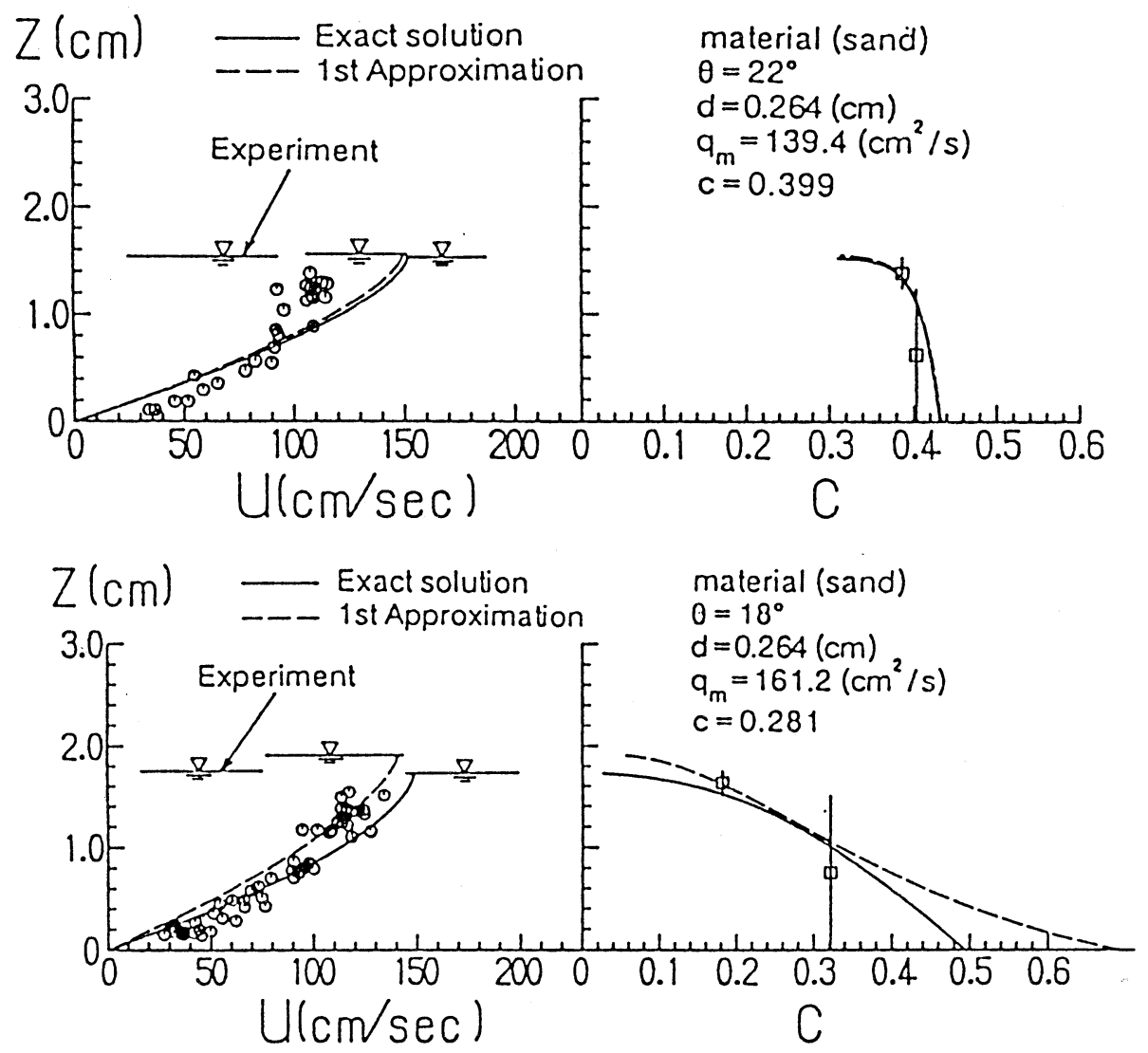

Fig. 6 Approximate and exact solutions and flume data for profiles of velocity and sediment concentration and flow depth of debris flow.

\section{3. 大規模な混相流の実例}

3. 1 St. Helens火山の噴火 $(1980)^{12)}$

1980年 5 月18日アメリカの St. Helens 火山が大爆発を起した。この噴火は今世紀最大と言 われるほど規模が大きく、噴出物の量は約 $1 \mathrm{~km}^{3}$ と見積られ、大気中に抎散した火山灰や火山 ガスの影響が全世界に及び、日本でも 6 月初旬に影響が及んでいることが確認された。 
この噴火では、さらに脹らんでいた山の北斜面がすべり出し、それに伴って生じた水蒸気爆 発で崩壊土塊が粉々に砕け、その間から立ち昇った微細粒子を多量に含む高温の真黒な雲が暴 風（blast）となって流れ出し、山の北側 $20 \mathrm{~km}$ 、東西 $30 \mathrm{~km}$ 範囲を破壞しつくした。いわゆ る火碎流である。一方、崩壞した山体（1～2 $\mathrm{km}^{3}$ ) は流動化して土石なたれ（debris avalanche）となり、山の北斜面を約 $8 \mathrm{~km}$ 流れ下り、山蚻に達して、前面に立ちはなかる比 高350〜 500 mの山塊に衝突した。その後、その大部分は西方向へ向きを変劣、2 度以下の緩い 河床勾配をもった North Fork Toutle川を埋めながら、さらに約 $23 \mathrm{~km}$ 流下して停止した。 堆積厚さは、土石なだれが山塊に衝突した付近では $100 \mathrm{~m}$ 越克、最先端部では約 $15 \mathrm{~m}$ とな て抢り、堆積幅は1〜2kmである。土石なだれの堆積後に、その堆積物の表面を大規模な泥

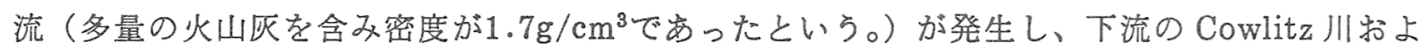
びさらに下流の Columbia 川に流入し、河床を $4.5 \mathrm{~m}$ か $8 \mathrm{~m}$ も上昇させた。下流部では氾濫 による災害を発生させた。泥流の流下距離は $100 \mathrm{~km}$ にも達した。以上の現象の影響範囲を示す と、Fig.7のと和りである。

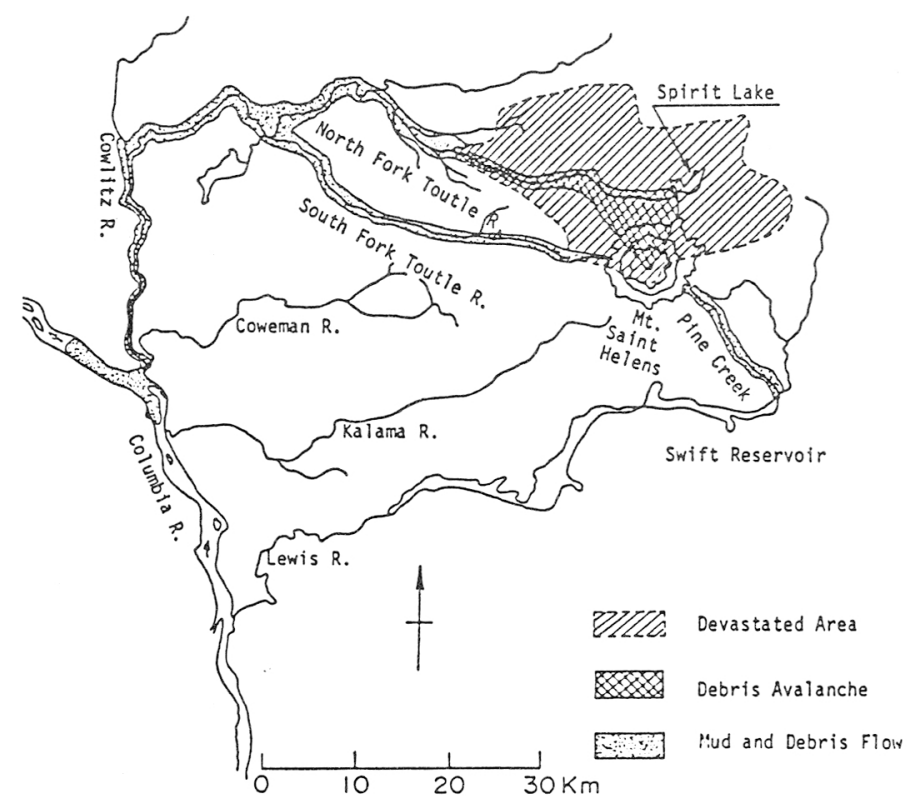

Fig. 7 Mapping of the devastated area and mud and debris flow at the Mt. St. Helens eruption.

高橋は、上述の blastの現象を火山死等の微細粒子を高濃度に含んだ空気が数 $100 \mathrm{~m}$ とい 厚い層を形成したために、密度流となって斜面に沿って流れ出したために生じた現象であると して、その力学機構を Bagnold の autosuspensionの概念を適用して説明している。

上述の土石なだれ（debris avalanche）は、山体の大規模崩壊にもとづく岩塊、土砂れき の崩壊であるが、流動性が高く、23kmを流下している。をた、堆積量の規模も極めて大きく、 堆積面積は約 $40 \mathrm{~km}^{2}$ であり、平均堆積厚さを $50 \mathrm{~m}$ と推定すると、堆積土量は約 $2 \mathrm{~km}^{3}$ 亿達する ことになる。なお、山体の新旧の等高線比較と崩壊前の山体の膨らみ量から崩垻による生産土 砂量は $1 \sim 2 \mathrm{~km}^{3}$ と推定されており、両者は一致する。 
堆積物の表面の形態は、極めて凹凸に富んでおり、凸出した部分は、もともと山体を形成し ていたものがブロック状に破壊されて流出した流れ山といわれるものである。このような堆積 形状からみても、土石なたれには、水はあまり含まれていなかった。

水を含まない岩塊がぞうして高い流動性を持って高速で流下したかについて、高橋は次の ように考察している。すなわち、彼は、高速のもとで、空気中に粒径 $1 \mathrm{~mm}$ 程度以下の微細粒 子が高濃度に浮遊して全体が高濃度の連続流体を形成し、その浮力効果によって、砂磷や岩塊、 流れ山が互いに衝突しながら分散し、流動したものであるとしている。すなわち、その流動の 機構は土石流と同じであるが、土石流は媒体が水あるいは微細粒子を高濃度に含む水であるの に対して、土石なだれでは、媒体が微細粒子を高濃度に含む空気である点が異なる。

大爆発が生じた約 4 時間後に、Spirit 湖から約 $10 \mathrm{~km}$ 下流の土石なだれ堆積物上で、先端部 に火山灰をまき上げながら流下して行く洪水（泥流）が確認されている。大量の火山灰と土石 なだれ中の細い成分とを含んだ洪水は極めて高濃度で、Toutle 川が Cowlitz川に合流する地

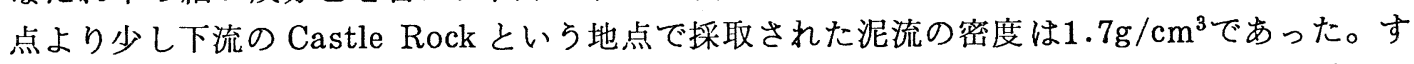
なわち、土石なだれの終端から約 $64 \mathrm{~km}$ 流下した地点でなお固体分の容積が約 $42 \%$ に達して いた。流れの状態はセメントペースト状であったと言う。この泥流が通過した後の土石なだれ 堆積物表面は、あたかもグレーダーで均した砂利道のように平滑化されており、また、ところ どころに、耳架状の典型的な泥流堆積物が見られた。この泥流は、下流に野積されていた大量 の木材を洗い流し、道路、橋、家屋等を流失させ大きな被害を与えた。この泥流で、North Fork Toutle 川から流出した水の総量は約 $0.04 \mathrm{~km}^{3}$ と推定されている。このよらな大量の水が どこから来たかについて高橋は山頂付近を覆っていた亦原が山体の崩壊と一緒に崩壊し、ブロッ ク状になって堆積物中に混合されていたものが溶けたため生じたるのであろらとしている。

なお、1991年 6 月にはフィリピンのピナツボ火山が噴火した。これは上述の St. Helens と 同様に今世紀最大規模のものであり、甚大な被害を与兄ている。

3.2 浅間山の火山噴火 (1783)

浅間山の火山活動は活潑で、日本書記に記载されている記録上の最古の噴火（685年）から 江戸時代の1868年の間に54回（1 年を 1 回として）の噴火が記録されている。平均して、22年 に 1 回の割合である。最近では、1958、1961、1973および1982年に噴火に伴なら火确流が発生 している。とくに、大きな被害を伴ったと推定される噴火は1108年と1783年（元明 3 年）のも のである。1783年の噴火では規模の大きい吾妻火砕流、鬼押出熔岩流および大規模泥流が発生 し大きな被害を与えた。この地域では現在開発が進んで来ており、かつての被害地には別荘地 やレジャー施設が整備されている。もし、同規模の現象が起きるとその被害は計り知れないも のになると想定される。したがって、1783年の噴火の際に生じた現象をでさるだけ詳しく再現 し、防災対策を樹てることが重要である。

幸い、当時の状況は古文書に詳しく記録されている。また、火确流については荒牧年, 年玉 によって調査が行なわれている。さらに、最近、財団法人砂防地すべり技術センターによっ て、火山泥流についての現地調査が行なわれている。これらを参考にして、1783年の噴火の際 に生じた大規模な混相流の実態について説明しょう。

1783年の一連の噴火の中で最も被害の大きかったものは鎌原火哗流である。これは、8月 5 日の午前10時頃発生し火口から鎌原村の方向へほぼ直線的に流下し、鎌原村を埋没させた。そ の本質噴出物の量は荒牧によると100 1000万 $\mathrm{m}^{3}$ 程度であり、また、砂防地すべり技術センター の土砂収支からの検討では、約 1800 万 $\mathrm{m}^{3}$ である。いずれにしても、1000万 $\mathrm{m}^{3}$ のオーダーであ るが、この火砕流は山体を浸食して、上述の土砂量を 1 オーダー上迴る多量の土砂磁を流下さ 
せた。その浸食の範团は、火口から水平距離で約 $5.5 \mathrm{~km}$ の鬼押出熔岩流の末端より少し上流か ら火口から約 $8 \mathrm{~km}$ 地点にわたっており、最大で約 $40 \mathrm{~m}$ の浸食崖を形成し、約 1 億 2,000 万 $\mathrm{m}^{3}$ の土砂量を流出させた。この大量の土砂は、下流の鎌原村を埋没させ、さらに下流に、大規模 な火山泥流となって吾妻川に流入し、さらに下流に伝播して利根川に入り甚大な被害をもたら

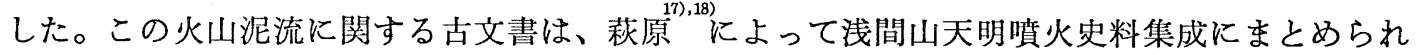
ている。

泥流の流下状況に関しては、古文書で数箇所の記載があり、段波状に流下したことが知られ る。これらの古文書から泥流の波高の縦断分布を示すとFig. 8 のとおりで、上流部では $30 \mathrm{~m}$ 程 度、下流に行く匡ど減少し、火口から $100 \mathrm{~km}$ 地点で $5 \mathrm{~m}$ 程度となっている。

泥流の到達時刻を古文書から整理したものがFig. 9 である。大規模な高濃度泥流の抵抗則は 明らかでないが、河川の洪水流によく用いられるマンニング則を用いて $n=0.05$ とて流速を 算出して、到達時刻を求めると古文書の記載時刻のほぽ中央の位置にプロットされる。これか ら火山泥流の流速に関しては、ほぼマンニング則が適用できることがわかる。また、Fig. 9 か

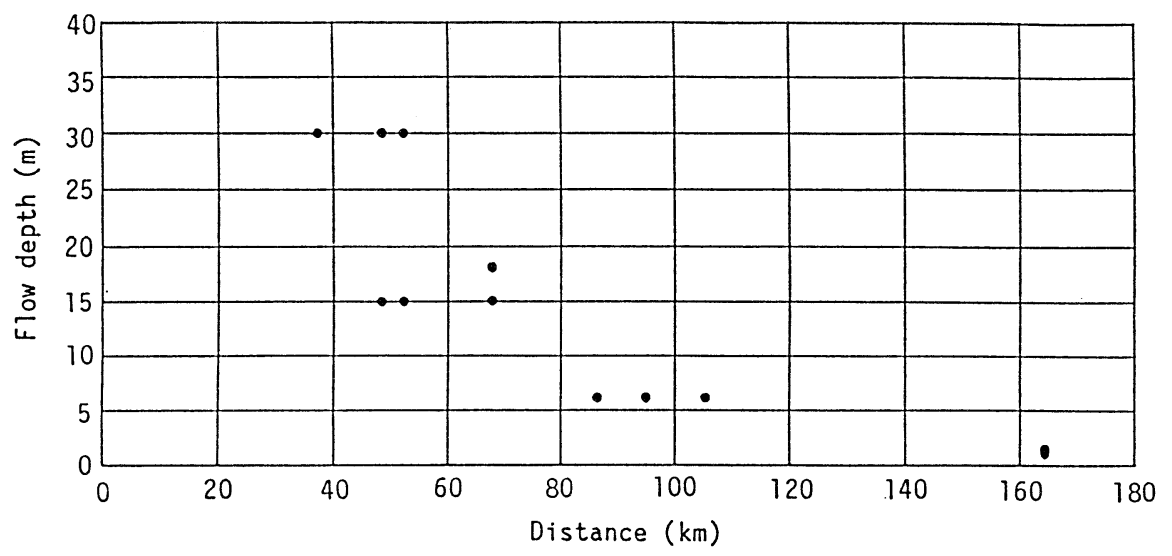

Fig. 8 Flow depth of the mud flow at the Mt.Asama eruption (1783).

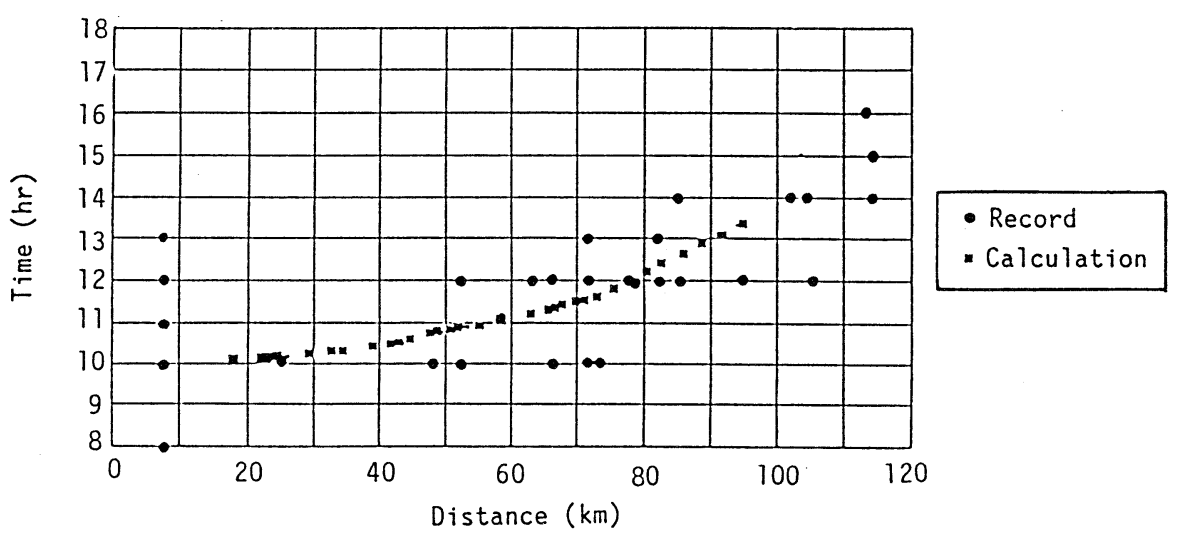

Fig. 9 Propagation of the mud flow at the Mt.Asama (1783). 
ら、火挽流から泥流の発生は一連の現象として起こっており、大規模な天然ダムが形成され、 それが破壊されて泥流が発生したというような現象ではなかったことがわかる。

波高と流速および流路幅から算出された泥流のピーク流量はFig.10のようで、利根川の現 在の計画高水量の10倍以上であって、いかに大規模な現象であったかがわかる。このような大 規模な泥流が、下流の吾妻川、さらに利根川に流入し、100km以上流下して大㷋害を与えたの である。

この泥流では、巨石が下流に運ばれて堆積した。古文書から、流下し堆積した巨石の径の縦 断分布をFig.11 に示している。直径10２0m程度の巨石が $100 \mathrm{~km}$ 下流まで運搬されたことは注 目に值するが、これは高濃度な流体の浮力効果と流体力によるものであろら。

この泥流についての土砂と水に関する収支の検討が砂防地すべり技術センターによってなさ れている。それによると、火口から $48 \mathrm{~km}$ 地点（群馬県原町）を通過した泥流の総量は 1 億 800 万 $\mathrm{km}^{3}$ 、泥流の土砂濃度 $32.1 \%$ 、泥流中に含まれる水の総量は 7,300 万 $\mathrm{m}^{3}$ となっている。この 事から知られるように大規模な泥流の主役は大量の水である。この水がどこから来たか現在種々 議論されている所で的確なことはわかっていない。

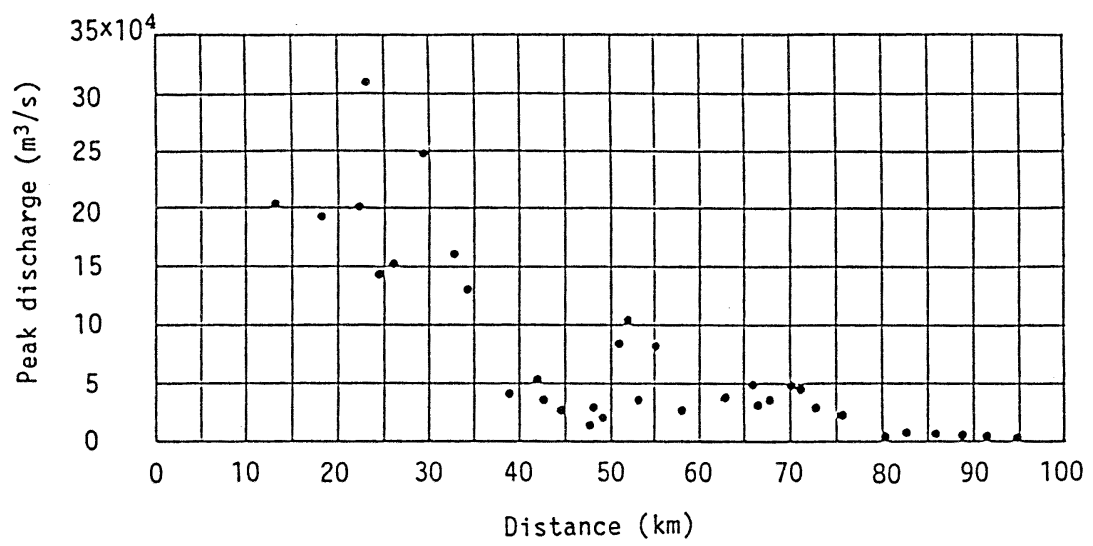

Fig. 10 Peak discharge of the mud flow at the Mt.Asama (1783).

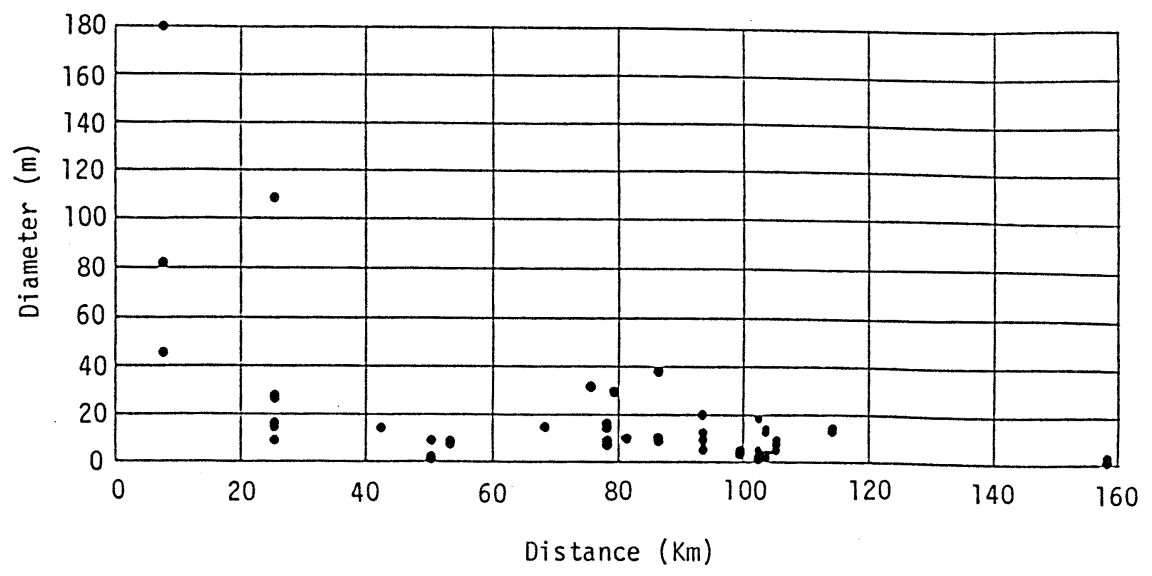

Fig. 11 Distribution of huge stone transported by the mud flow (1783). 
現在の鬼押出の末端付近に絵図、古文書では「柳井沼」といら沼があったことが示されてい る。また、この付近（標高 $1200 \mathrm{~m}$ 付近）は現在涌水点が分布している地点である。この事から、 火山山麓の山体はポーラスな堆積物で、多量の地下水が含まれていて、これが山体の浸食とと もに流出し、火砕流堆積物や山体浸食土砂のなかの微細な成分を巻き込んで大規模な泥流が発 生したのではないかと著者は考えている。一般に、火山地帯においては、しばしば大規模な泥 流が発生するが、これは火山山体に含をれる大量の水によるものであろう。この事を確かめる ためには、火山地带における水収支の実態を明らかにすることが必要である。

3 . 3 長野県西部地震による御岳くずれ（1984）

1984年 9 月 14 日御岳山南麓を震央とするM6.8の地震が発生し、王滝川流域で多数の斜面 崩壊が生じた。その最大のものは、御岳山 8 合目付近に発生した御岳くずれで、崩壊土量は約 3,600万 $\mathrm{m}^{3}$ であった。これは、1911年に発生した稗田山崩れの 1 億 5,000 万 $\mathrm{m}^{3}$ に次いで、今世 紀における我が国第 2 位の規模の崩壊である。

この崩壊は、御岳山の標高 $1900 \mathrm{~m} \sim 2500 \mathrm{~m}$ の斜面において発生した。その規模は、長さ 1480 $\mathrm{m}$ 、最大幅 $480 \mathrm{~m}$ 、最大深 $150 \mathrm{~m}$ （鉛直方向）であった。崩壊源の火山堆積物は、土砂磁および 軽石層などから構成されており、上部を熔岩層が薄く覆っていた。軽石層は風化による粘土化 がかなり進んでおり軟弱であり、これが直下型地震によって大きな加速度を受けて破壊したこ

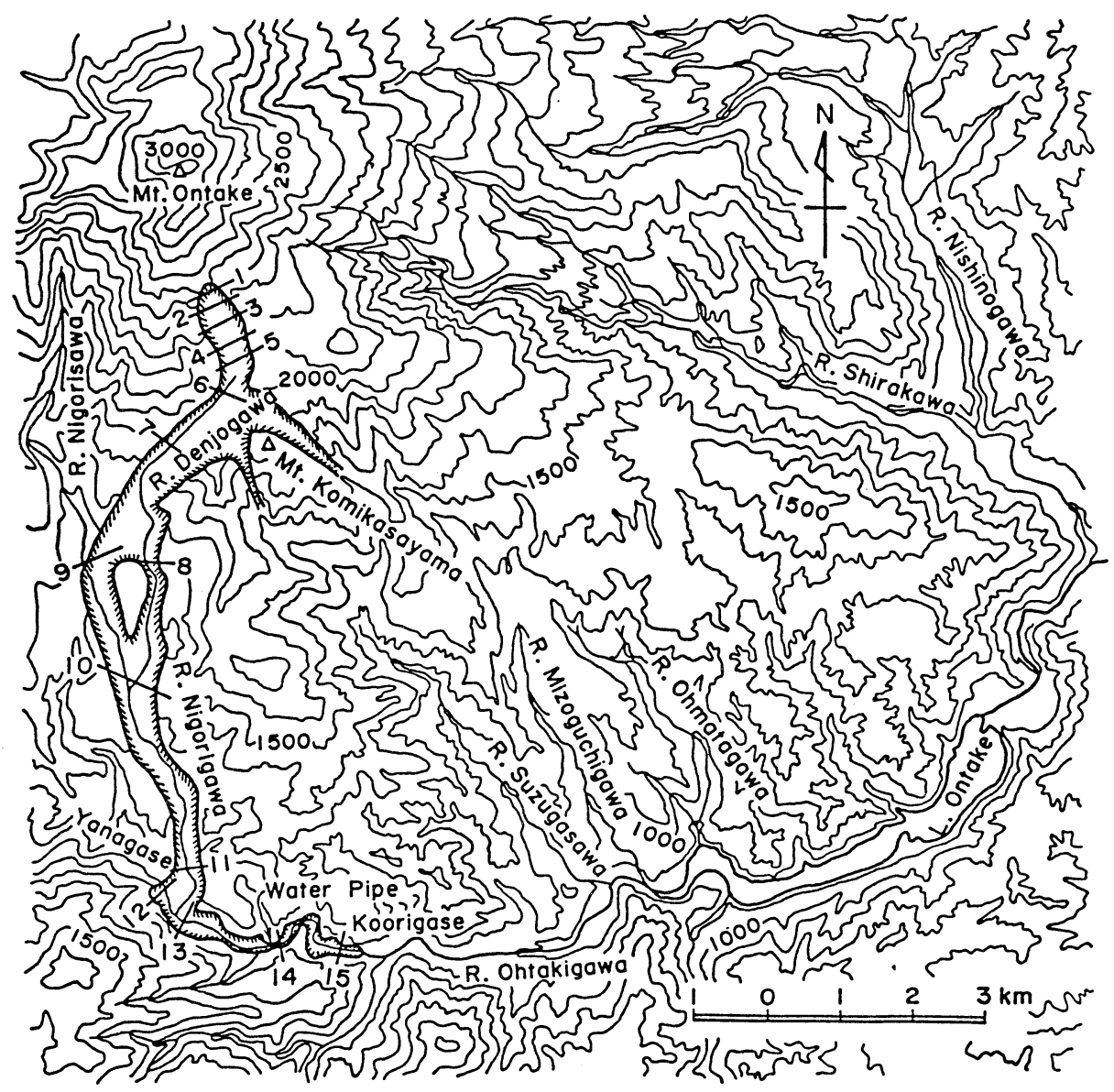

Fig. 12 The trace of debris flow at the Ontake land slide. 
とが大崩壊の直接的な原因である。

崩壊によって生産された大量の土砂は、大規模な土石流となって、Fig.12に示すように伀 上川 $\rightarrow$ 濁川 $\rightarrow$ 王滝川の経路で流出した。その過程において、湓流や顕著な浸食・堆積現象を 伴っている。まず、崩土の一部は崩壊地直下流の比高 $100 \mathrm{~m}$ の尾根（小三笠山）を溢流してい る。本体は伝上川を流下したが、その直線部においては河岸高から $100 \mathrm{~m}$ 越える領域にも明 瞭な流下痕跡が残されている。したがって土石流の流動深は $100 \mathrm{~m}$ 越えており、しかも河道 の浸食痕跡から考えて土石流の移動速度はかなり大きかったことが推察される。土石流の本体 は、平均勾配 $7 \sim 8$ ○伝上川の河床や側岸を浸食して樹木や表土を巻き込みながら流下し、 標高 $1600 \mathrm{~m}$ の地点で、右岸側の比高 $100 \mathrm{~m}$ 程度の尾根部において一部は再度溢流し濁沢に入っ て堆積した。本体はさらに流下して濁川に入った。この付近から下流は河床の勾配が緩るくなっ ているため、土石流はその一部とくに流れ山の部分を堆積させながらさらに流下し、王滝川本 川に流出した。王滝川本川の河床勾配は 1 。程度であるので、土石流は急激に堆積しながら先 端部は約 $4 \mathrm{~km}$ 下流の水ケ瀬付近まで流下して停止した。王滝川合流点付近の堆積深は最大で $40 \mathrm{~m}$ 程度、堆積幅は $300 \mathrm{~m}$ 及んだ。土石流の発生源と堆積場所を縦断図に示したものが Fig. 13 である。

堆積物は岩塊・土砂磁等から榗成されているが、災害直後の調査では流れ山の部分を除いて 水を十分に含み泥々の状態であった。その後に行われたボーリングの結果では堆積物の深部に おいても同様の状態であって土石流として流下したことが推察された。一般の土石流では、渓 床勾配が $3 \sim 4^{\circ}$ 位までの範囲に停止しているが、この大規模な土石流では流動性が高く勾配

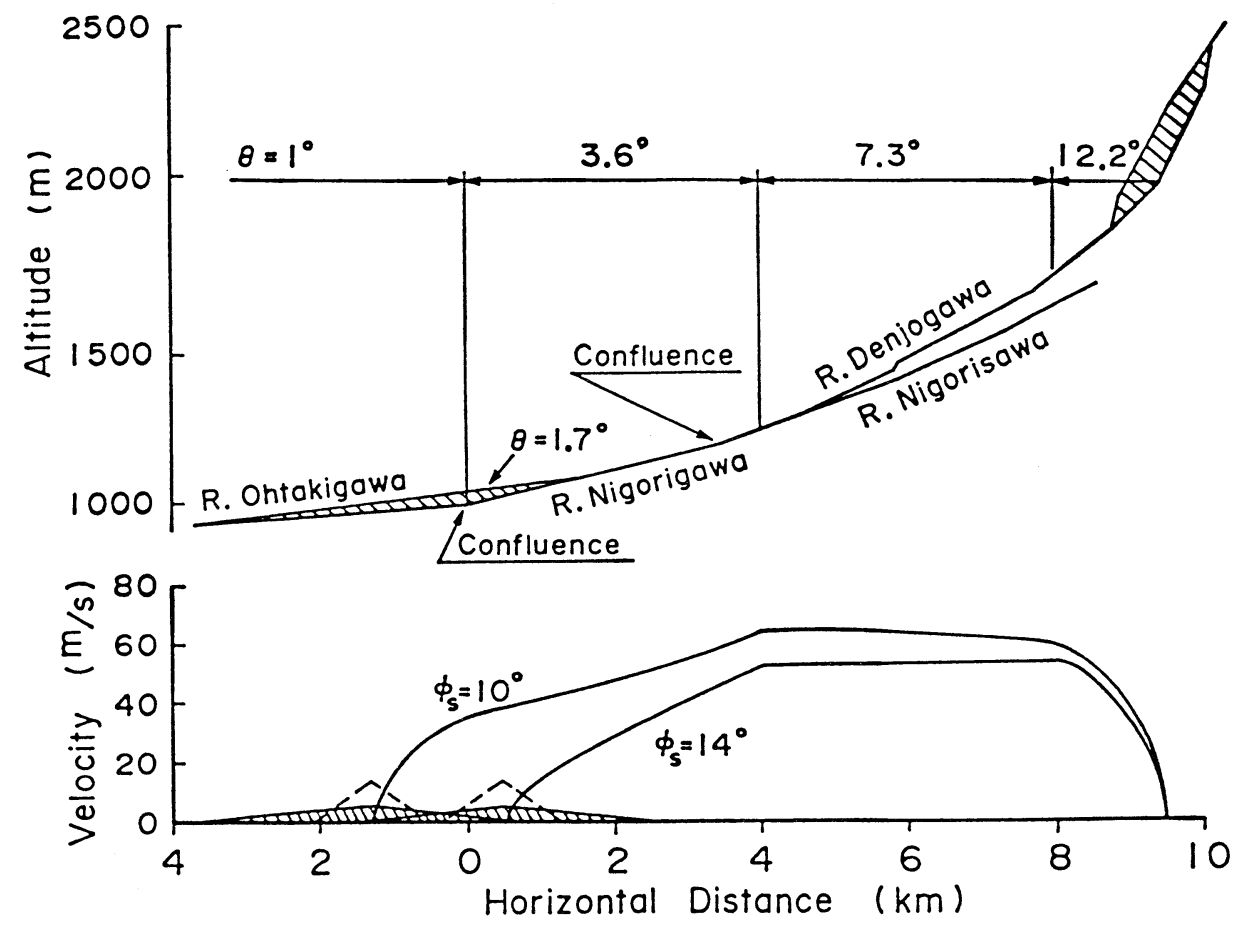

Fig. 13 Profiles of bed level before and after the Ontake land slide, and moving velocity of soil block calculated by the authors. 
1 。程度の所まで流出していることは與味ある事実である。

一般に崩壊規模が大きくなるほど流動性を増し、崩壊源から停止点むでの見かけの摩擦係数 $\mu_{\mathrm{e}}$ はFig.14 に示すように減少することが知られている。同図には、我が国の歴史的に著名 な大崩壊と御岳くずれの值を示している。御岳くずれは他の崩壊に比してもかなり流動性が高 いことが伺觉る。

著者らは、流れ山を含む土砂磁や岩塊が緩勾配の所をどうして高速で流れることができるか について検討を行なった。この原因として、高压の空気が岩塊を支えて滑っていくという空 気クッション説少も用いられたことがあるが、最近では否定的意見が多い。御岳くずれの場合 についても大量の土砂磁や岩塊を支えるだけの空気を取り込んだは考えにくい。また、この 説では、流動の過程において生じているはげしい浸食や流動化した堆積物の状況を説明するこ とができない。したがって、この説は否定することができる。考えうる可能性としては、微細 粒子を高濃度に含む水あるいは空気による流体を媒体として形成された土石流あるいは土石な だれのいずれかである。

土塊が高速で移動している時には、間吵水あるいは空気は乱流となり、その乱れによって粒 子のうち細粒分は浮遊し、混合して一種の流体となる。高濃度になるほど流体の密度は増加す る。一方砂䃯分のらち一部が流体と見なせるようになるため、固体分の割合が減少する。すな わち、流体の浮力効果と固体の摩擦の減少効果によって固体摩擦抵抗は減少し流動性は高くな る。著者らは、このような考察から、御岳くずれは上の二つの可能性のうち微細粒子を高濃度 に含む水を媒介として形成された土石流であると推論した。
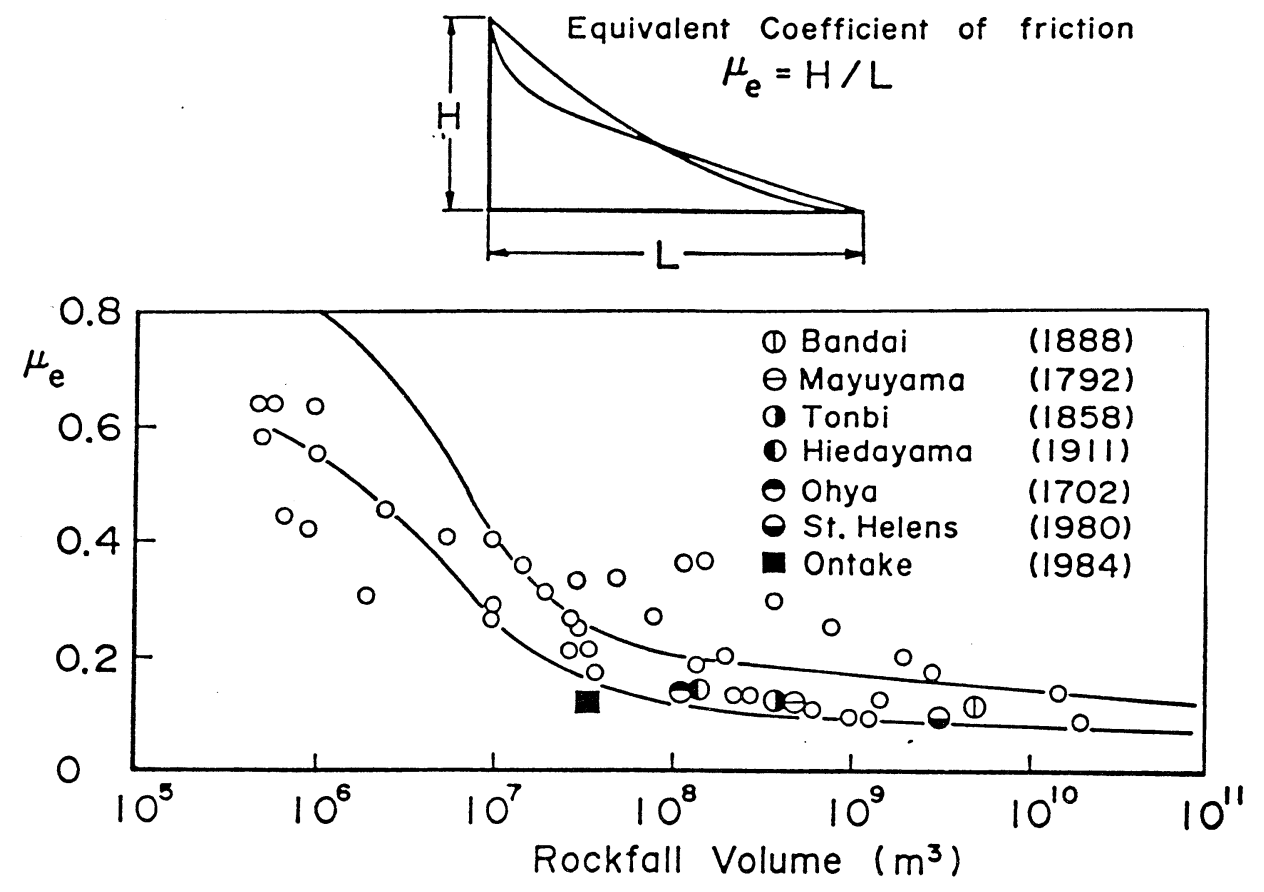

Fig. 14 The relations of equivalent coefficient of friction to rook fall volume for historical land slides in the world. 
しかし、高速で高濃度な流れの乱流の構造や粒子の浮遊機構に関しては未解明な所が多く、 的確な議論は今後に残されている。また、土石流を形成するためには大量の水が必要であるが、 それがどこにどのように存在していたかについては十分解明されているわけではない。しかし、 著者らは、ポーラスな火山山体に地下水として含まれていたのではないかと考えている。

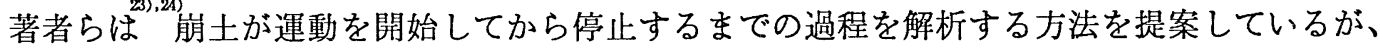
それを用いて御岳くずれの解析を行なった。結果をFig.13 に示している。計算は内部摩擦角 $\varphi_{\mathrm{s}}=10^{\circ}$ および $\varphi_{\mathrm{s}}=14^{\circ}$ の二つの場合について行なっているが、いずれも、運動を開始すると 急激に加速して、定常速度に達し、平均勾配 $3.6^{\circ}$ 付近から減速域に入り、しばらく流下して 停止する。これらのことは実際の状況をかなり良く説明している。また、計算から求めた土塊 の平均移動速度は約 $35 \mathrm{~m} / \mathrm{s}$ となりこれに対して聞き込み調査などから推定されているものは $20 \sim 30 \mathrm{~m} / \mathrm{s}$ の範囲となっている。

\section{4. 結 語}

（1）自然界には、雪崩、火碀流、岩晚流、土石流、泥流など災害の原因となる混相流が存 在し、とくに、天変地異に付随して現われる大規模な混相流は大災害を引き起こす。

(2) 観测および実験から明らかにされた土石流の実態について述べ、さらに土石流の発生 条件を示した。

（3）土石流の流動に関して、エネルギー散逸に関する考察に基づいて応力と歪速度の関係 を求めて構成式を誘導し、それを適用して、土石流の流速分布と濃度分布式を表わし た。

（4）大規模な混相流の実例として、1）セントヘレンズ火山の噴火に伴なって発生した火 砕流、岩屑流および泥流、2）浅間山の噴火に伴なって発生した火砕流と泥流および 3 ）長野県西部地震によって発生した御岳くずれによる大規模土石流を取り上げて、 その実態を説明するとともに、流動機構について考察した。

\section{参考文献}

（1）奥田節夫ほか 4 名：京都大学防災研究所年報第20号 B-1（1977）.

（2）高橋 保：京都大学防災研究所年報第20号 B-2（1977）.

（3）芦田和男・高橋 保・道上正：河川の土砂災害と対策、森北出版 (1983).

（4）芦田和男・高橋 保：土木学会誌 6、2-17 (1983).

( 5 ) Bagnold, R.A. : Proc. Royal Society of London, A, Vol. 225 (1954).

（6）椿東一郎・橋本晴行・末次忠司：土木学会論文集, N317（1982）.

(7) Ackerman, N.L. and Shen, H. : Proc. ASCE, Vol.108, No.EM1 (1982).

(8) Shen, H and Ackerman, N.L. : Proc. ASCE, Vol.108, No.EM5 (1982).

（9）金谷健一：流体工学 Vol.14, No.12 (1978).

（10）宮本邦明：Newton 流体を含む粒子流の流動機構に関する研究、立命館大学学位論文 (1985).

（11）江頭進治・芦田和男 - 矢島 啓・高濱淳一郎：京都大学防災研究所年報、第 32 号 B-2 (1989).

（12）高橋 保：京都大学防災研究所年報第24号 A （1981）.

(13) Bagnold, R.A. : Proc. Royal Society of London, A. No.1322 (1962). 
（14）荒牧重雄：浅間山の地質、地団研専報 Vol.14（1968）.

（15）荒牧重雄：火山噴火に伴う乾燥粉体流の特質と災害、文部省科研費自然災害特別研究、 (1986).

（16）児玉幸多：天明 3 年浅間山大噴火による埋没村落（鎌原村）の発掘調查、文部省科研費 報告書 (1982).

（17）萩原 進：浅間山天明噴火資料集成 II 記録編（一)、群馬県文化事業振興会 (1986).

（18）萩原 進：浅間山天明噴火資料集成 III 記録編（二)、群馬県文化事業振興会 (1989).

(19) Hsü, K. : Gelogical Soc. American Bull, Vol.86, (1975).

（20）町田 洋: 地形 5 巻 3 号, (1984).

（21）芦田和男 - 江頭進治：京都大学防災研究所年報第28号 B-2（1985）.

(22) Shreve, R.L. : Science, Vol.154 (1966).

（23）芦田和男 - 江頭進治 - 大梘英樹：京都大学防災研究所年報、第26号 B-2（1983）.

（24）芦田和男 - 江頭進治・神矢 弘：京都大学防災研究所年報、第27号 B-2（1984）. 